\title{
Pengembangan Lembar Kerja Siswa Berbasis Kontekstual Berorientasi Penalaran Saintifik
}

\author{
Yulia Florenty Lamapaha ${ }^{1}$ \\ ${ }^{1}$ SMPN Unggulan Ohoijang. Jl. Soekarno-Hatta, Langgur Kab. Maluku Tenggara, Maluku, Indonesia. \\ * Korespondensi Penulis. E-mail: yuliaflorenty@ymail.com \\ Received:10 January 2017; Revised:10 March 2017; Accepted: 10 April 2017
}

\begin{abstract}
Abstrak
Penelitian ini bertujuan untuk menghasilkan lembar kerja siswa berbasis kontekstual yang berorientasi pemberdayaan penalaran saintifik siswa. Penelitian dilakukan menggunakan metode penelitian pengembangan model. Perangkat pembelajaran yang dikembangkan dalam penelitian ini adalah silabus, RPP, LKS berbasis kontekstual, dan instrumen penilaian penalaran saintifik siswa. Perangkat pembelajaran dikembangkan dalam konteks materi ekosistem pantai berbatu. Hasil penelitian menunjukkan bahwa lembar kerja siswa berbasis kontekstual ini dinilai baik pada semua indikator penilaian yang dilakukan oleh validator (ahli media pembelajaran, ahli materi pembelajaran, guru biologi dan teman sejawat). LKS berbasis CTL materi ekosistem pantai berbatu yang memenuhi kriteria ekosistem atas dasar komponen penyusunnya berpengaruh meningkatkan penalaran saintifik siswa karena menggunakan sintaks CTL yang benar, terlihat pada nilai siswa yang mengalami peningkatan ditinjau dari skor pre-test dan post-test sebelum dan sesudah menggunakan LKS berbasis CTL yang dikembangkan, serta terdapat perbedaan yang signifikan pada data post-test hasil belajar siswa pada kelas eksperimen dan kelas kontrol.
\end{abstract}

Kata Kunci: LKS, CTL, Penalaran Saintifik

\section{Developing of Contextual-Based Student Worksheet Oriented to Reasoning Scientific}

\begin{abstract}
This research aimed to produce a contextual-based student worksheet oriented to empowerment of student scientific reasoning. The study was conducted using the method of model development research. Learning kit which developed in this study were the syllabus, lesson plans, contextual-based student worksheets, , and instrument of students scientific reasoning. The learning kit was developed in the context of learning materials rocky shore ecosystems. The results showed that the contextualbased student worksheet considered good in all indicators of assessment conducted by the validator (learning media expert, learning materials expert, biology teachers and peers). Contextual-student worksheet on material rocky shore ecosystems that meet the criteria on the basis of its constituent components increased the students' scientific reasoning cause using contextual syntax right, looks at the value of students who have increased in terms of the scores of pre-test and post-test before and after use student worksheet developed contextually based, and there were significant differences in the data post-test results of students in the experimental class and the control class.
\end{abstract}

Keywords: LKS, CTL, Scientific Reasoning

How to Cite: Lamapaha, Y. (2017). Pengembangan lembar kerja siswa berbasis kontekstual berorientasi penalaran saintifik. Jurnal Pendidikan Matematika dan Sains, 5(1). doi:http://dx.doi.org/10.21831/jpms.v5i1.13541

Permalink/DOI: DOI: http://dx.doi.org/10.21831/jpms.v5i1.13541 


\section{PENDAHULUAN}

Abad 21 ditandai dengan terjadinya peningkatan pengetahuan dan teknologi. Berbagai temuan penting dalam bidang teknologi informasi telah mengubah pola hidup masyarakat dunia saat ini. Perkembangan teknologi dan informasi yang terjadi secara cepat ini sangat membutuhkan individu yang mampu terus ber-adaptasi dengan perubahanperubahan tersebut. Hampir semua bidang kehidupan membutuhkan individu yang terampil menggunakan teknologi dan mengelola informasi. Kemampuan untuk berdaptasi dengan perkembangan teknologi dan informasi sangat ditentukan oleh keterampilan-keterampilan berpikir dan membuat keputusan.

Hal ini direspons oleh sistem pendidikan dengan menjadikan keterampilan berpikir tingkat tinggi sebagai orientasi utama dalam pembe-lajaran, termasuk pembelajaran sains. Karena itu, reformasi pendidikan sains menitikberatkan pem-belajaran untuk memberdayakan kemampuan berpikir dan bernalar secara saintifik. Arah baru pembelajaran sains adalah (1) kemampuan dan kebiasaan untuk mengkonstruksi pengetahuan, (2) memahami konsep sentral dari teori-teori sains dan (3) kemampuan untuk mengkomunikasikan konsep kepada orang lain (Prain \& Yore, 2001; Lawson, 2004; Sandoval \& Reiser, 2003).

Arah baru pendidikan sains ini bertujuan menciptakan masyarakat yang melek sains (science literacy) di masa depan. Konsepsi pembelajaran sains ini dapat dicapai jika siswa dilatih dan dibekali dengan kemampuan bernalar secara saintifik. Penalaran merupakan keterampilan ber-pikir yang paling prinsip dan esensial dalam kehidupan sehari-hari. Secara operasional, pena-laran saintifik adalah serangkaian proses berpikir sistematis yang dimulai dari mengevaluasi argu-men, menguji hipotesis, mengumpulkan bukti, membuat penyimpulan dan membuat keputusan (Metallidou et al., 2012). Penalaran saintifik memiliki peran yang penting bagi siswa dalam pembelajaran.

Siswa yang dapat bernalar dengan baik dapat memahami konsep-konsep sains dengan benar dan mudah melakukan perubahan pada struktur pengetahuannya (Williams et al., 2004; Ya-wen \& She, 2009). Menurut Schunn \& Anderson (1999), penalaran saintifik adalah jenis berpikir ini melibatkan banyak sekali proses kognitif. Manfaat-manfaat akademik maupun sosial penalaran saintifik menyebabkan muncul-nya berbagai penelitian yang mengkaji penalaran saintifik.

Penalaran saintifik merupakan salah satu jenis berpikir yang berkembang sangat lamban karena dipengaruhi oleh berbagai faktor, (Goswami \& Bryant, 2007). Ada beberapa faktor yang mempengaruhi perkembangan penalaran sain-tifik, antara lain kematangan bagian otak seperti dorsolateral prefrontal cortex (DFC) dan parietal cortex (Crone et al., 2009), lobus prefrontal (Ju-Kwon et al., 2000) dan peningkatan materi putih (white matter) (Ferrer, O'Hare \& Bunge, 2009).

Dengan berkembangnya metode-metode analisis otak, banyak penelitian sudah dilakukan untuk mengetahui bagaimana otak belajar atau bernalar. Bagian otak yang berperan dalam pena-laran adalah lobus frontal. Parsons \& Osherson, (2001) juga menemukan bahwa penalaran deduk-tif dan induktif melibatkan dua bagian otak yang berbeda. Penalaran induktif melibatkan hemisfer otak sebelah kiri yaitu frontal interior, cingulate posterior, parahipocampal, medial temporal dan korteks prefrontal. Sedangkan penalaran deduktif lebih pada hemisfer otak kanan yang berkaitan dengan daerah yang berperan dalam bahasa.

Selain faktor biologis, metakognisi merupakan faktor pendorong perkembangan penalaran saintifik (Scheiner, 2008; Khun, 2000). Bao et al. (2009) menyatakan bahwa penalaran saintifik dapat dikembangkan melalui pembelajaran. Ciri pembelajaran yang dapat memicu perkembangan penalaran saintifik adalah pembelajaran relevan dengan faktorfaktor yang dibutuhkan untuk perkembangannya. Berdasarkan kutipan-kutipan tentang perkembangan penalaran saintifik, perkembangan otak merupakan faktor yang dominan, meskipun ada faktor-faktor lain. Pembelajaran pun harusnya dirancang sesuai dengan pola perkembangan otak. Pembelajaran kontekstual adalah salah satu jenis pembelajaran yang relevan dengan pola-pola kerja otak pada umumnya.

Pembelajaran kontekstual merupakan perpaduan banyak praktik pembelajaran yang baik dan beberapa pendekatan reformasi pendidikan yang dimaksudkan untuk memperkaya relevansi dan penggunaan fungsional pendidikan untuk semua siswa. Johnson (2009) menambahkan bahwa, "CTL is an educational process that aims to help students see meaning in the 
academic material they are studying by connecting academic subjects with the context of their daily lives, that is, with context of their personal, social, and cultural circumstance". Dari definisi tersebut dapat diartikan bahwa, CTL adalah sebuah proses pendidikan yang bertujuan untuk membantu siswa melihat makna dalam materi akademik yang mereka pelajari dengan menghubungkan mata pelajaran akademik dengan konteks kehidupan sehari-hari mereka, yaitu, dengan konteks keadaan pribadi, sosial dan budaya mereka. Beberapa hasil penelitian menunjukkan bahwa pembelajaran dengan CTL efektif ditinjau dari motivasi dan prestasi belajar (Laili, 2016) dan pembelajaran menggunakan modul berbasis CTL meningkatkan keterampilan proses sains dan sikap ilmiah siswa (Rinsiyah, 2016)

Pembelajaran kontekstual dapat direalisasikan dengan mengembangkan bahan ajar bentuk Lembar Kerja Siswa. LKS adalah panduan siswa yang digunakan untuk melakukan kegiatan penyidikan atau pemecahan masalah. LKS dapat berupa panduan untuk latihan pengembangan aspek kognitif maupun panduan untuk pengem-bangan semua aspek pembelajaran dalam bentuk panduan eksperimen dan demonstrasi (Trianto, 2009). Materi pembelajaran berbasis kontekstual yang dituangkan dalam bahan ajar diharapkan dapat membantu siswa untuk bernalar secara saintifik.

Berdasarkan uraian tersebut, maka sangat diperlukan adanya pengembangan LKS berbasis kontekstual pada materi ekosistem pantai berbatu untuk meningkatkan penalaran saintifik siswa. Dengan demikian tujuan penelitian ini adalah untuk menghasilkan LKS berbasis kontekstual pada materi ekosistem pantai berbatu untuk meningkatkan penalaran saintifik siswa yang berkualitas.

\section{METODE}

\section{Jenis Penelitian}

Penelitian ini merupakan penelitian pengembangan menggunakan model pengembangan Borg \& Gall (1983). Produk yang dikem-bangkan adalah LKS berbasis kontekstual yang diharapkan dapat meningkatkan penalaran sain-tifik (scientific reasoning) siswa. Selain LKS, perangkat pembelajaran lainnya yang dikem-bangkan dalam penelitian ini adalah silabus, RPP dan instrumen tes penalaran saintifik siswa.
Perangkat pembelajaran dikembangkan dalam konteks materi Ekosistem Pantai Berbatu.

\section{Prosedur Pengembangan}

Prosedur pengembangan yang digunakan dalam penelitian ini mengikuti model pengembangan yang telah dipilih. Langkah-langkah pengembangan produk perangkat pembelajaran selanjutnya mengikuti model Borg \& Gall (1983) yaitu (1) studi pendahuluan, (2) perencanaan, (3) desain produk, (4) uji coba produk, (5) validasi produk, dan (6) produk akhir.

\begin{tabular}{|c|c|c|}
\hline $\begin{array}{l}\text { Studi } \\
\text { Pendahuluan: } \\
\text { 1. Literatur } \\
\text { 2. Lapangan. } \\
\text { 3. Pembelajaran }\end{array}$ & $\begin{array}{l}\text { Perencanaan: } \\
\text { 1. Defenisi } \\
\text { operasional } \\
\text { 2. Subjek } \\
\text { penelitian }\end{array}$ & \begin{tabular}{ll}
\multicolumn{2}{l}{ Desain Produk: } \\
1. & Silabus \\
2. & RPP \\
3. & LKS . \\
4. Instrumen \\
& penilaian
\end{tabular} \\
\hline $\begin{array}{l}\text { Produk Akhir: } \\
\text { LKS berbasis } \\
\text { CTL materi } \\
\text { Ekosistem } \\
\text { Pantai Berbatu. }\end{array}$ & $\begin{array}{l}\quad \text { Uji Coba } \\
\quad \text { Produk: } \\
\text { 1. Uji Terbatas } \\
\text { 2. Revisi II } \\
\text { 3. Uji klp besar } \\
\text { 4. Revisi III }\end{array}$ & $\begin{array}{l}\text { Validasi } \\
\text { Produk: } \\
\text { 1. Validasi } \\
\text { produk awal. } \\
\text { 2. Revisi I }\end{array}$ \\
\hline
\end{tabular}

Gambar 1. Prosedur Pengembangan Perangkat

Penelitian diawali dengan studi pustaka dan survei lapangan. Studi pustaka dilakukan untuk mengetahui perkembangan penelitian dalam bidang Pendidikan Sains. Berdasarkan kajian literatur, diketahui bahwa tujuan Pendidikan Sains Abad 21 adalah meningkatkan kemampuan berpikir tingkat tinggi (high order thinking) siswa dimana penalaran saintifik (scientific reasoning) merupakan bagian dari kemampuan berpikir yang esensial bagi siswa. Oleh karena itu, ber-bagai upaya intervensi pembelajaran sangat penting dilakukan agar siswa dapat bernalar secara saintifik

Mendesain pembelajaran untuk meningkatkan penalaran saintifik siswa dapat dilakukan dengan mengembangkan alat bantu pembelajaran yang dapat mendorong dan melatih siswa ber-nalar secara saintifik. LKS merupakan alat bantu pembelajaran yang melatih siswa belajar secara mandiri sehingga diyakini dapat menndorong peningkatan penalaran saintifik siswa. Selain itu, pendekatan kontekstual juga merupakan pola pembelajaran yang sangat membantu siswa mengaitkan 
fenomena di lingkungan sekitar dengan materi pembelajaran. Oleh karena itu, materi yang relevan dengan pembelajaran kon-tekstual adalah materi ekosistem.

Berkaitan dengan karakteristik Kabupaten Maluku Tenggara yang merupakan sasaran utama pengembangan produk LKS, sebagian wilayahnya terdiri atas lingkungan perairan pantai berbatu. Oleh karena itu, pembelajaran yang kontekstual seharusnya dilakukan dengan memanfaatkan karakteristik pantai berbatu. Dengan demikian, uji coba produk LKS berbasis kontekstual dapat dilakukan dengan mengambil lokasi Kabupaten Gunung Kidul Yogyakarta karena memiliki karakteristik pantai yang mirip. Survei yang dilakukan pada SMA Negeri 2 Wonosari juga mendapati bahwa letak sekolah yang dekat dengan pantai. Selain itu, LKS berbasis kontekstual juga belum pernah dikembangkan dan diterapkan pada siswa. Oleh karena itu, penelitian ini dapat dilakukan untuk pada SMA Negeri 2 Wonosari Kabupaten Gunung Kidul Yogyakarta.

Berdasarkan hasil studi kepustakaan mengenai dasar-dasar teori dan konsep pembelajaran serta survei lapangan, maka peneliti menyusun draft awal perangkat pembelajaran. Dalam tahapan pengembangan, dilakukan penyu-sunan produk dan uji ahli dan uji coba lapangan. Uji ahli dilakukan dengan menggunakan expert yaitu ahli dalam media pembelajaran dan ahli materi. Ahli yang diminta memberi penilaian terhadap produk LKS berasal dari dosen PPs Universitas Negeri Yogyakarta. Selain itu, uji ahli juga menggunakan guru bidang studi Biologi yang berasal dari Kabupaten Maluku Tenggara maupun SMA Negeri 2 Wonosari. Saran dan komentar ahli kemudian dijadikan sebagai bahan revisi sebelum perangkat diujicobakan secara langsung kepada siswa.

Penilaian kelayakan draft produk LKS dilakukan oleh ahli, guru mata pelajaran dan rekan sejawat. Penilaian kelayakan produk dilakukan dari segi kelayakan sebagai alat bantu pembelajaran, kelayakan isi produk LKS serta keterbacaan. Penilaian kelayakan sebagai alat bantu pembelajaran dan kelayakan materi produk LKS berbasis kontesktual dilakukan oleh dosen biologi PPs Universitas Negeri Yogyakarta. Penilaian keterbacaan LKS berbasis kontekstual dilakukan oleh guru mata pelajaran biologi dari Kabupaten Maluku Tenggara dan SMA Negeri 2 Wonosari. Selain itu, dilakukan pula penilaian oleh rekan sejawat untuk memberikan masukkan dan saran dalam menyempurnakan draft produk LKS berbasis kontekstual.

Selain penilaian terhadap produk LKS, dilakukan pula analisis terhadap instrumen yang digunakan untuk mengukur sikap dan penalaran saintifik siswa. Langkah-langkah penyusunan dan penilaian instrumen meliputi: (1) penentuan indikator penilaian, (2) penyusunan butir soal, (3) konsultasi dengan ahli serta, (4) revisi butir soal berdasarkan masukan ahli.

Revisi 1 dilakukan berdasarkan hasil penilaian kelayakan perangkat yang dilakukan oleh ahli media, ahli materi, guru dan rekan sejawat. Hasil revisi 1 akan disempurnakan dalam bentuk draft kedua yang akan diuji coba secara langsung pada siswa.

Prosedur selanjutnya yaitu uji coba terbatas yang dilakukan dengan hanya mengambil satu kelas yaitu kelas X SMA. Uji coba dilakukan sebanyak 5 kali pertemuan. Hasil uji coba terbatas kemudian dianalisis dan dilakukan revisi pada bagian-bagian yang masih memiliki kekurangan. Hasil revisi tahap II akan menjadi bahan untuk dilakukan uji coba pada kelompok siswa yang lebih besar.

Uji coba lapangan diterapkan pada 1 kelas pada kelas X SMA. Pada tahap ini dilakukan pembelajaran dan observasi. Kegiatan dilakukan sama dengan kegiatan yang dilakukan pada uji coba terbatas. Perbedaannya adalah pada uji lapangan, subjek uji coba lebih banyak. Data hasil uji coba lapangan selanjutnya dianalisis sebagai bahan penyempurnaan produk LKS berbasis kontekstual.

\section{Desain Uji Coba Produk}

Uji coba produk merupakan bagian tak terpisahkan dari pengembangan perangkat pembelajaran. Uji coba produk dibagi menjadi 2 tahapan yaitu (1) uji coba terbatas dan (2) uji coba lapangan atau kelompok besar. Uji coba lapangan dilakukan dengan menggunakan desain ekspe-rimen model pretest-postest nonequivalent control group design yang digambarkan pada Tabel 1.

Tabel 1. Prosedur Eksperimen Pretest-Postest Non-Equivalent Control Group Design.

\begin{tabular}{cccc}
\hline Group & Pretes & Treatment & Postes \\
\hline KE & O1 & X1 & O2 \\
KK & O3 & X2 & O4 \\
\hline
\end{tabular}

(Diadaptasi dari Furchan, 2004)

Keterangan:

$\mathrm{X} 1$ = Pembelajaran dengan LKS berbasis CTL 
$\mathrm{X} 2$ = Pembelajaran Konvensional

\section{Subjek Uji Coba}

Subjek coba adalah siswa kelas $\mathrm{X}$ dan guru biologi kelas X SMAN 2 Wonosari.

Tabel 2. Sebaran Jumlah Subjek Uji Coba

\begin{tabular}{|c|c|c|c|}
\hline \multirow{2}{*}{ Jenis Subjek } & \multicolumn{2}{|c|}{ Uji Coba } & \multirow{2}{*}{$\mathrm{Jlh}$} \\
\hline & Terbatas & Lapangan & \\
\hline Siswa & 15 & 30 & 45 \\
\hline Guru & & 1 & 1 \\
\hline
\end{tabular}

Jenis Data

Jenis data dalam penelitian ini berupa data kualitatif dan kuantitatif. Data kualitatif diperoleh pada penelitian berupa saran atau komentar dari validator. Data kuantitaif diperoleh dari skor tanggapan validator terhadap LKS skor penalaran saintifik.

\section{Instrumen Pengumpulan Data}

Instrumen yang digunakan dalam pengumpulan data dalam penelitian ini antara lain:

\section{Lembar validasi $L K S$}

Instrumen ini digunakan untuk mengukur kevalidan lembar kerja siswa. Penilaian kevalidan LKS yang dikembangkan ditinjau dari 3 aspek, yaitu: (1) organisasi LKS (2) bahasa dan (3) isi. Kriteria untuk menyatakan bahwa LKS yang dikembangkan adalah valid terdiri atas 5 skala penilaian.

Tabel 3. Skala Penilaian Produk.

\begin{tabular}{clc}
\hline No & Kriteria & Skala \\
\hline 1 & sangat kurang & nilai 1 \\
2 & Kurang & nilai 2 \\
3 & Cukup & nilai 3 \\
4 & Baik & nilai 4 \\
5 & sangat baik & nilai 5 \\
\hline
\end{tabular}

Instrumen ini digunakan untuk mengukur kevalidan perangkat pembelajaran yang dikembangkan yaitu (1) lembar validasi produk LKS untuk ahli media, (2) lembar validasi produk LKS untuk ahli materi, (3) lembar validasi produk LKS untuk guru, dan (5) lembar validasi produk LKS untuk rekan sejawat. Lembar Validasi Instrumen Tes Penalaran Saintifik digunakan untuk mengetahui validitas instrumen penalaran saintifik siswa.

\section{Teknik Analisis Data}

Analisis data dalam penelitian ini bertujuan untuk menjawab pertanyaan penelitian. Data yang berupa komentar, saran, revisi, dan hasil observasi selama proses uji coba dianalisis secara deksriptif kualitatif dan disimpulkan sebagai masukkan untuk merevisi produk yang dikem-bangkan. Sedangkan, data yang berupa skor tanggapan ahli, skor dan skor penalaran saintifik siswa.

Data berupa skor tanggapan validator yang diperoleh dalam bentuk kategori yang terdiri dari lima pilhan tanggapan tentang kualitas produk perangkat pembelajaran yang dikembangkan, yaitu: sangat kurang (nilai 1), kurang (nilai 2), cukup (nilai 3), baik (nilai 4), dan sangat baik (nilai 5).

Selain masukan dan saran validator perangkat pembelajaran dikatakan efektif untuk digunakan uji coba jika rata-rata skor tiap perangkat pembelajaran mempunyai kategori baik. Maka hasil analisis data yang tidak memenuhi kategori baik pada penelitian ini akan dijadikan bahan pertimbangan untuk merevisi perangkat sebelum diujicobakan. Tes Penalaran Saintifik dilakukan dengan menggunakan statistik deskriptif dan statisik inferensial. Analisis deskriptif, untuk melihat gambaran terkait penalaran saintifik siswa sebelum dan sesudah pembelajaran. Analisis Kovarians, untuk melihat pengaruh LKS berbasis kontekstual terhadap penalaran saintifik. Apabila ada pengaruh yang signifikan, dilanjutkan dengan uji beda Least Significance Difference (LSD).

\section{HASIL DAN PEMBAHASAN}

\section{Penilaian Silabus}

Penilaian silabus dilakukan terhadap sistematika silabus hasil pengembangan. Penilaian silabus dilakukan oleh ahli media pembelajaran, ahli materi dan guru bidang studi biologi yang lebih senior. Rangkuman hasil penilaian silabus disajikan pada Tabel 4.

Tabel 4. Hasil Penilaian Silabus

\begin{tabular}{clc}
\hline No. & \multicolumn{1}{c}{ Sistematika } & Rerata \\
\hline 1 & Judul & 3,79 \\
2 & Kompetensi Inti & 3,86 \\
3 & Materi Pokok & 3,86 \\
4 & Kegiatan Pembelajaran & 3,71 \\
5 & Indikator & 3,71 \\
6 & Penilaian & 3,86 \\
7 & Alokasi waktu & 3,71 \\
8 & Sumber belajar & 3,57 \\
\hline
\end{tabular}

Hasil penilaian silabus yang tertera pada Tabel 4 menjelaskan bahwa rata-rata skor untuk yang 
diberikan validator untuk judul silabus adalah 3,79, kompetensi inti sebesar 3,86, materi pokok sebesar 3,86, kegiatan pembelajaran sebesar 3,71, indikator sebesar 3,71, penilaian sebesar 3,86, alokasi waktu sebesar 3,71 dan sumber belajar sebesar 3,57. Dengan demikian silabus yang dikembangkan telah memenuhi kategori valid dan dapat digunakan untuk kegiatan pembelajaran.

\section{Penilaian RPP}

Proses pembelajaran dalam penelitian ini dikelola dengan menggunakan acuan berupa rencana proses pembelajaran (RPP). Perangkat RPP dikembangkan dan dinilai oleh ahli pembelajaran, guru dan teman sejawat. Penilaian RPP dilakukan untuk mengetahui kesahihan dari setiap indikator dalam RPP. ahli terhadap RPP hasil pengembangan disajikan pada Tabel 5.

Tabel 5. Hasil Penilaian RPP oleh Validator

\begin{tabular}{clc}
\hline No. & \multicolumn{1}{c}{ Sistematika } & Rerata \\
\hline 1. & Identitas RPP & 4,71 \\
2. & Kompetensi Inti & 4,86 \\
3. & Kompetensi Dasar & 4,57 \\
4. & Indikator & 5,00 \\
5. & Tujuan Pembelajaran & 4,57 \\
6. & Materi Pembelajaran & 4,86 \\
7. & Model dan Metode Pembelajaran & 4,71 \\
8. & Media, Alat, dan Sumber Pembelajaran & 4,79 \\
9. & Langkah-Langkah Pembelajaran & 4,81 \\
10. & Penilaian & 4,71 \\
\hline \multicolumn{2}{c}{ Rerata } \\
\hline
\end{tabular}

Hasil penilaian RPP yang tertera pada Tabel 5 menjelaskan bahwa rata-rata skor yang diberikan oleh validator terhadap sistematika RPP, yaitu: identitas RPP adalah sebesar 4,71, kompetensi inti sebesar 4,86, kompetensi dasar adalah 4,57, indikator adalah sebesar 5,00, tujuan pembe-lajaran adalah 4,57, materi pembelajaran adalah 4,86, model dan metode pembelajaran adalah 4,71, media dan sumber pembelajaran adalah 4,79, langkah-langkah pembelajaran adalah sebe-sar 4,81 serta penilaian sebesar 4,71. Secara keseluruhan ratarata skor yang diberikan vali-dator terhadap RPP hasil pengembangan adalah 4,76. Dengan demikian, dapat disimpulkan bahwa RPP hasil pengembangan adalah valid dan dapat digunakan.

\section{Penilaian LKS}

Pengembangan LKS dilakukan pada materi Ekosistem Pantai Berbatu. Materi dikembangkan dengan pendekatan Contextual Tea- ching Learning. Produk LKS hasil pengembangan selanjutnya di validasi oleh pakar dan pakar pembelajaran. Penilaian produk LKS dilakukan terhadap indikator-indikator, sistematika produk LKS berbasis kontekstual. Hasil penilaian produk LKS ahli disajikan pada Tabel 6.

Tabel 6. Hasil Penilaian Produk LKS

\begin{tabular}{clc}
\hline No. & \multicolumn{1}{c}{ Indikator } & Rerata \\
\hline 1 & Pendahuluan & 4,76 \\
2 & Tujuan Pembelajaran & 4,79 \\
3 & Materi Pokok & 4,71 \\
4 & Desain Percobaan & 4,81 \\
& Langkah & \\
5 & penyelidikan & 4,79 \\
6 & Pertanyaan untuk diskusi & 4,90 \\
\hline \multicolumn{2}{c}{ Rerata } & $\mathbf{4 , 7 9}$ \\
\hline
\end{tabular}

Penilaian LKS dilakukan oleh 7 orang yang terdiri dari 2 orang ahli, 3 orang guru dan 2 teman sejawat. Hasil penilaian produk LKS yang tertera pada Tabel 10 menjelaskan bahwa rata-rata skor penilaian pada indikator pendahuluan adalah 4,76. Rata-rata skor indikator tujuan pembe-lajaran adalah sebesar 4,76, materi pokok 4,71, desain percobaan adalah sebesar 4,81, langkah melakukan penyelidikan adalah sebesar 4,79 dan pertanyaan untuk diskusi adalah 4,79. Secara keseluruhan rata-rata skor penilaian produk LKS berbasis kontekstual adalah sebesar 4,79. Dengan demikian, dapat disimpulkan bahwa LKS berbasis kontekstual sudah dinyatakan valid dan dapat digunakan.

\section{Uji Coba Kelompok Terbatas}

Pengukuran penalaran saintifk siswa dilakukan dengan menggunakan instrumen penelitian berupa soal tes yang dimodifikasi berdasarkan instrumen yang dikembangkan oleh Lawson (2004). Tipe soal tes penalaran saintifik adalah multiple choice yang dilengkapi dengan alasan sehingga dapat dikatakan benar jika jawaban dan alasan benar. Pengukuran penalaran saintifik siswa dilakukan sebelum (pretest) dan sesudah pembelajaran (postest). 


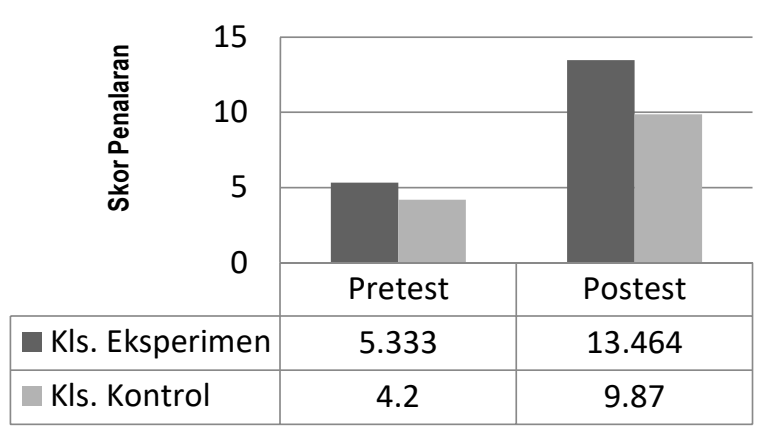

Gambar 2. Skor Skor Penalaran Saintifik

Hasil analisis deskriptif memperlihat bahwa rata-rata skor penalaran saintifik siswa kelas ekspe-rimen pada pelaksanaan pretes adalah sebesar 5,333. Rata-rata nilai penalaran saintifik siswa ini berada pada kategori peralihan antara fase penalaran konkrit dan penalaran formal. Pada kelompok kontrol, rata-rata penalaran saintifik siswa sebelum pembelajaran adalah sebesar 4,200. Nilai penalaran siswa ini berada pada kategori penalaran konkrit.

Rata-rata penalaran saintifik siswa kelas eksperimen pada pelaksanaan postest adalah sebesar 13,464. Nilai penalaran saintifik siswa ini berada pada kategori penalaran formal. Pada kelas kontrol, rata-rata penalaran saintifik siswa sesudah pembelajaran adalah sebesar 9,870. Nilai penalaran saintifik siswa ini berada pada kategori peralihan yaitu fase antara penalaran konkrit dan penalaran formal.

Hasil tes penalaran saintifik siswa juga dianalisis secara inferensial dengan menggunakan jenis statistik analisis kovarians. Sebagai persyaratan analisis kovarians, terlebih dahulu dilakukan uji asumsi untuk mengetahui normalitas kelompok data dari masing-masing variabel data. Analisis normalitas data dilakukan dengan menggunakan uji stastistik non parametrik One Sample Kolmogorov-Smirnov. Hasil uji normalitas data disajikan pada Tabel 7.

Tabel 7. Ringkasan Hasil Uji Normalitas Data dengan Uji One Sample Kolmogorov-Smirnov Test terhadap Variabel Terikat

\begin{tabular}{ccc}
\hline Variabel & P. & Alpha \\
\hline PS & 0,088 & 0,05 \\
\hline
\end{tabular}

Tabel 7 menunjukkan bahwa nilai probabilitas (sig.) dari masing-masing variabel terikat yang diuji lebih besar dari nilai alpha yang digunakan yaitu 0.05. Dengan demikian H0 diterima, artinya bahwa tidak ada penyimpangan terhadap norma-litas data setiap variabel bebas sehingga data variabel terikat dinyatakan berdistribusi normal.

Uji homogenitas data dilakukan terhadap data terkoreksi dari setiap kelompok data penelitian yaitu rata-rata skor penalaran saintifik siswa. Hasil perhitungan uji homogenitas antar varian yang dilakukan dengan teknik statistik Leven's Test of Equality of Error Variances terhadap variabel terikat disajikan pada Tabel 8.

Tabel 8. Ringkasan Hasil Uji Homogenitas antar Varian Data Variabel Terikat

\begin{tabular}{ccccc}
\hline Variabel & F & df1 & df2 & Sig. \\
\hline PS & 0,437 & 1 & 28 & 0,514 \\
\hline
\end{tabular}

Tabel 8 menunjukkan bahwa nilai probabilitas (sig.) dari masing-masing variabel terikat yang diuji lebih besar dari nilai alpha yang digunakan yaitu 0.05. Dengan demikian $\mathrm{H}_{0}$ diterima, artinya bahwa tidak ada perbedaan varian antar kelom-pok data sehingga data variabel terikat dinyata-kan homogen.

Berdasarkan hasil uji prasyarat yang menyatakan bahwa data pemahaman konsep siswa berdistribusi normal dan homogen sehingga analisis dapat dilanjutkan dengan analisis kovarians untuk mengetahui pengaruh perangkat pembelajaran terhadap penalaran saintifik siswa.

Tabel 9. Hasil Analisis Kovarians Pengaruh Perangkat Pembelajaran Terhadap Penalaran Saintifik Siswa.

\begin{tabular}{lccccc}
\hline Source & $\begin{array}{c}\text { Type } \\
\text { III Sum } \\
\text { of } \\
\text { Squares }\end{array}$ & df & $\begin{array}{c}\text { Mean } \\
\text { Square }\end{array}$ & F & Sig. \\
\hline Pretes & 0,238 & 1 & 0,238 & 0,462 & 0,503 \\
Kelas & 60,088 & 1 & 60,088 & 116,754 & 0,000 \\
Error & 13,896 & 27 & 0,515 & & \\
Total & 202,000 & 30 & & & \\
Corrected & 18,667 & 29 & & & \\
Total & & & & & \\
\hline
\end{tabular}

Berdasarkan Tabel 9 dapat dijelaskan bahwa nilai $F_{\text {hitung }}$ sebesar 116,754 dengan singnifikansi 0,000 . Nilai ini lebih kecil dibandingkan dengan nilai alpha 0,05 yang digunakan untuk pengujian sehingga dengan demikian $\mathrm{H} 0$ yang menyatakan bahwa "tidak ada pengaruh perangkat pembelajaran terhadap penalaran saintifik siswa "ditolak dan konsekuensinya hipotesis penelitian yang menyatakan bahwa "terdapat pengaruh LKS terhadap penalaran saintifik siswa" diterima. 
Rata-rata terkoreksi skor penalaran saintifik siswa pada kelas eksperimen adalah 13,464 yang berbeda nyata dan lebih tinggi dari rata-rata penalaran saintifik siswa pada kelas kontrol yaitu 9,870. Dengan demikian dapat disimpulkan bahwa perangkat pembelajaran yang dikembangkan dapat meningkatkan penalaran saintifik siswa.

\section{Uji Coba Lapangan}

Berdasarkan hasil uji coba terbatas, dilakukan perbaikan terhadap bagian-bagian LKS yang kurang dapat diikuti dengan baik oleh siswa. Revisi dilakukan terhadap struktur maupun isi. Setelah itu, LKS diujicobakan pada siswa pada kelompok yang lebih besar untuk mengetahi pengaruhnya teradap peningkatan penalaran sain-tifik siswa.

Hasil analisis data secara deskriptif memperlihatkan bahwa pada kelompok eksperimen yang menggunakan LKS pengembangan, ratarata penalaran saintifik siswa pada pretes adalah sebesar 4,400 yang berada pada kategori penalaran konkrit. Rata-rata penalaran saintifik siswa pada kelompok eksperimen setelah pembelajaran dengan menggunakan LKS meningkat menjadi 13,067 yang berada pada kategori penalaran formal. Pada kelas kontrol, rata-rata penalaran saintifik siswa pada pelaksanaan pretes adalah sebesar 3,533 yang berada pada kategori pena-laran konkrit. Ratarata penalaran saintifik siswa pada kelompok kontrol sesudah pembelajaran adalah sebesar 9,833 yang berada pada kategori fase peralihan antara penalaran konkrit dan penalaran formal.

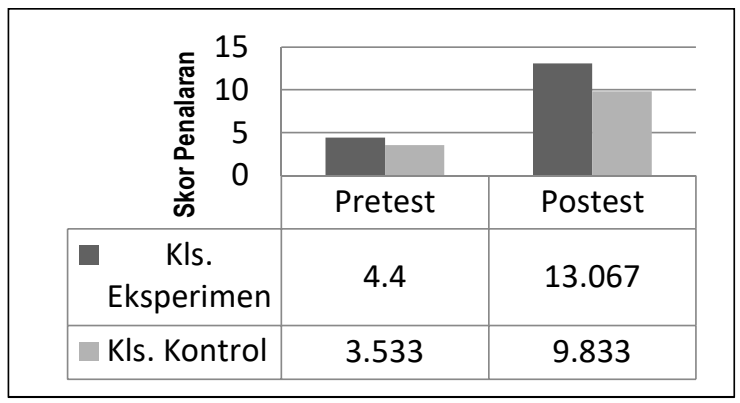

Gambar 3. Skor Skor Penalaran Saintifik

Sebagai persyaratan analisis kovarians, terlebih dahulu dilakukan uji asumsi untuk mengetahui normalitas kelompok data dari masing-masing variabel data. Analisis normalitas data dilakukan dengan menggunakan uji stastis-tik non parametrik One Sample Kolmogorov-Smirnov. Ringkasan hasil uji normalitas data terhadap variabel terikat dapat dilihat pada Tabel 10.

Tabel 10. Ringkasan Hasil Uji Normalitas Data dengan Uji One sample Kolmogorov-Smirnov Test terhadap Variabel Terikat.

\begin{tabular}{ccc}
\hline Variabel & P. & Alpha \\
\hline Penalaran saintifik & 0,063 & 0,05 \\
\hline
\end{tabular}

Tabel 10 menunjukkan bahwa nilai probabilitas (sig.) dari masing-masing variabel terikat yang diuji lebih besar dari nilai alpha yang digunakan yaitu 0,05. Dengan demikian H0 diterima, artinya bahwa tidak ada penyimpangan terhadap norma-litas data setiap variabel bebas sehingga data variabel terikat dinyatakan berdistribusi normal.

Uji homogenitas data dilakukan terhadap data terkoreksi dari setiap kelompok data penelitian yaitu rata-rata skor data penalaran saintifik dan sikap siswa. Hasil perhitungan uji homogenitas antar varian yang dilakukan dengan teknik statistik Leven's Test of Equality of Error Variances terhadap variabel terikat disajikan selengkapnya pada Lampiran 8b, sedangkan ringkasan hasil uji homogenitas antar varian data dapat dilihat pada Tabel 11.

Tabel 11. Ringkasan Hasil Uji Homogenitas antar Varian Data Variabel Terikat

\begin{tabular}{ccccc}
\hline Data Varian & F & df1 & df2 & Sig. \\
\hline PS & 3,656 & 1 & 58 & 0,061 \\
\hline
\end{tabular}

Tabel 11 menunjukkan bahwa nilai probabilitas (sig.) dari masing-masing variabel terikat yang diuji lebih besar dari nilai alpha yang digunakan yaitu 0,05. Dengan demikian H0 diterima, artinya bahwa tidak ada perbedaan varian antar kelom-pok data sehingga data variabel terikat dinyata-kan homogen.

Berdasarkan hasil uji prasyarat yang menyatakan bahwa data penalaran saintifik dan sikap siswa berdistribusi normal dan homogen sehingga analisis dapat dilanjutkan dengan analisis kovarians untuk mengetahui pengaruh perangkat pembelajaran terhadap penalaran saintifik siswa. Hasil analisis kovarians selengkapnya dapat dilihat pada Tabel 12.

Tabel 12. Hasil Analisis Kovarians Pengaruh Perangkat Pembelajaran Terhadap Penalaran Saintifik Siswa.

\begin{tabular}{lccccc}
\hline Source & $\begin{array}{c}\text { Type III } \\
\text { Sum of } \\
\text { Squares }\end{array}$ & df & $\begin{array}{c}\text { Mean } \\
\text { Square }\end{array}$ & F & Sig. \\
\hline Pretes & 0,919 & 1 & 0,919 & 0,781 & 0,381 \\
\hline
\end{tabular}




\begin{tabular}{lccccc}
\hline Kelas & 123,639 & 1 & 123,639 & 105,006 & 0,000 \\
Error & 67,114 & 57 & 1,177 & & \\
Total & 8091,000 & 60 & & & \\
Corrected & 224,850 & 59 & & & \\
Total & & & & & \\
\hline
\end{tabular}

Hasil analisis kovarians menunjukkan bahwa $F_{\text {hitung variabel Kelas besar 105,006 dengan }}$ tingkat signifikansi 0,000. Nilai ini lebih kecil dibandingkan dengan nilai alpha 0,05 yang digunakan untuk pengujian sehingga dengan demikian $\mathrm{H}_{0}$ yang menyatakan bahwa "tidak ada pengaruh perangkat pembelajaran terhadap penalaran saintifik siswa "ditolak dan konsekuensinya hipotesis penelitian yang menyatakan bahwa "terdapat pengaruh strategi pembelajaran terhadap pemahaman konsep siswa" diterima.

Rata-rata terkoreksi skor penalaran saintifik siswa pada kelas eksperimen adalah 13,144 yang berbeda nyata dan lebih tinggi dari ratarata penalaran saintifik siswa pada kelas kontrol yaitu 9,756. Dengan demikian dapat disimpulkan bah-wa perangkat pembelajaran yang dikembangkan dapat meningkatkan penalaran saintifik siswa.

Peningkatan skor penalaran saintifik pada kelas eksperimen kelompok terbatas dan uji coba lapangan mengindikasikan bahwa LKS yang dikembangkan telah cukup efektif. LKS berbasis kontekstual mampu meningkatkan skor pena-laran saintifik siswa lebih baik dibanding dengan siswa pada kelas kontrol.

LKS merupakan salah satu alternatif pembelajaran yang tepat bagi siswa, karena membantu siswa untuk menambah informasi tentang konsep yang dipelajari melalui kegiatan belajar secara sistematis dan dalam kegiatan pembelajaran guru mendapat kesempatan untuk memancing siswa agar secara aktif terlibat pada materi yang sedang dibahas. sehingga meminimalkan peran guru, tetapi memaksimalkan peran siswa, memudahkan siswa untuk memahami materi yang diberikan, ringkas dan kaya tugas untuk berlatih, memudahkan pelaksanaan pengajaran kepada siswa. Berikut sistematika LKS umumnya menurut Trianto (2009).

Hasil pengembangan LKS yang berbasis kontekstual terbukti dapat meningkatkan penalaran saintifik siswa dengan baik. LKS hasil pengembangan membantu siswa untuk menghubungkan konsep-konsep sains secara teoritis dengan fakta yang ada di lingkungan sehari-hari. Siswa dapat dengan mudah menemukan dan mengenali komponen-komponen dalam materi ekosistem pantai berbatu pada lingkungan sehari-hari. Konsep-konsep yang dipelajari dalam LKS merupakan fakta di lingkungan sekitar. Kekayaan alam yang ada di lingkungan sekitar dijadikan bahan pembelajaran dalam kelas. Ciri pembe-lajaran semacam ini membantu siswa untuk ber-adaptasi dengan perubahan-perubahan yang ter-jadi di lingkungan.

Dengan LKS berbasis kontekstual, siswa dilatih untuk mengkonstruksi pengetahuan secara saintifik berdasarkan fakta yang ditemui di ling-kungan sekitar. Jika diterapkan secara konsisten dalam pembelajaran, siswa akan terbiasa mengi-kuti pembelajaran secara sistematis. Hal ini akan berdampak pada peningkatan kemampuan ber-nalar secara saintifik. Siswa dilatih untuk meng-interpretasi fakta di lingkungan secara saintifik. Menghubungkan gejala-gejala ekologis yang tampak di lingkungan sekitar dengan perangkat penalaran yang telah dimiliki.

\section{SIMPULAN}

Berdasarkan hasil analisis data dan pembahasan dapat disimpulkan bahwa telah berhasil dikembangan LKS Berbasis CTL materi ekosistem pantai berbatu untuk siswa kelas X SMA yang layak digunakan untuk meningkatkan pena-laran saintifik dan kelayakan didasarkan pada indikator pengembangan produk yang termuat dalam kajian teori. LKS berbasis CTL ini dinilai baik pada semua indikator penilaian yang dila-kukan oleh validator (ahli media pembelajaran, ahli materi pembelajaran, guru biologi dan teman sejawat).

LKS berbasis CTL materi ekosistem pantai berbatu yang memenuhi kriteria ekosistem atas dasar komponen penyusunnya berpengaruh ter-hadap peningkatan penalaran saintifik siswa karena menggunakan sintaks CTL yang benar, terlihat pada nilai siswa yang mengalami pening-katan ditinjau dari skor pretest dan post-test sebelum dan sesudah menggunakan LKS ber-basis CTL yang dikembangkan, serta terdapat perbedaan yang signifikan pada data post-test hasil belajar siswa pada kelas eksperimen dan kelas kontrol.

Berdasarkan kesimpulan yang telah dikemukakan, maka ada beberapa saran yang dapat disampaikan dari penelitian ini. Pertama, LKS berbasis CTL hasil pengembangan telah terbukti valid dan dapat digunakan secara luas pada materi ekosistem pantai berbatu kelas X SMA. Kedua, LKS ini dapat diterapkan pada semua sekolah terutama sekolah-sekolah yang memiliki 
karakeristik daerah pesisir seperti Kabupaten Maluku Tenggara dan Kabupaten Gunung Kidul. Ketiga, perlu dilakukan penelitian lanjutan untuk mengembangkan LKS berbasis CTL pada materi pembelajaran lainnya yang ada pada kelas $\mathrm{X}$ dan diujicobakan efektivitasnya dalam meningkatkan pemahaman konsep maupun keterampilan-kete-rampilan berpikir tingkat tinggi lainnya seperti berpikir kritis, problem solving maupun berpikir kreatif.

\section{DAFTAR PUSTAKA}

Azwar, S. (1995). Sikap Manusia: Teori dan Pengukurannya Edisi Kedua. Yogyakarta: Pustaka Pelajar.

Bao Lei., Kai Fang., Tianfang Cai., Jing Wang., Lijia Cui., Jiung Han., Lin Ding., \& Ying Lou. (2009). Learning of content know-ledge and development of scientific rea-soning ability: A cross culture compari-son. American Journal of Physic. 77 (12), $1118-1123$.

Borg, R. W. \& Gall M. D (1983). Educational research: An introduction $\left(4^{\text {th }} \mathrm{Ed}\right.$.). New York: Longmn Inc.

Crone, E. A., Wendelken, C., Leijenhorst, van L., Honomichl, R. D., Christoff, K., \& Bunge, S. A. (2009). Neurocognitive development of relational reasoning. Developmental Science 12 (1), 55- 66.

Ferrer, E., O'Hare, E. D., \& Bunge, S. A. (2009). Fluid reasoning and the developing brain. Frontiers in Neuroscience, 3 (1).

Furchan, A. H. (2004). Pengantar Penelitian dalam Pendidikan. Yogyakarta: Pustaka Pelajar.

Goswami, U. \& Bryant, P. (2007) Children's cognitive development and learning (Primary Review Research Survey 2/la), Cambridge: University of Cambridge Faculty of Education.

Johnson, E. B. (2009). Contextual teaching and learning: What it is and why it's here to stay (Terjemahan Ibnu Setiawan). Bandung: MLC.

Kuhn, D. \& Pearsall, S. (2000). Developmental origins of scientific thinking. Journal of Cognition and Development, 1 (1), 113 -129 .

Laili, H. (2016). Keefektifan pembelajaran dengan pendekatan CTL dan PBL ditinjau dari motivasi dan prestasi belajar matematika. PYTHAGORAS: Jurnal Pendidikan Matematika, 11 (1), 25 doi:http://dx.doi.org/10.21831/pg.v11i1. 9679

Lawson, A. E. (2004). The nature and development of scientific reasoning: A synthetic view. International Journal of Science and Mathematics Education, 2 (1), 307-338

Metallidou, P., Diamantidou, E., Konstantinopoulou, E., \& Megari, K. (2012). Changes in children's beliefs about everyday reasoning: evidence from greek primary students. Australian Journal of Educational \& Developmental Psycho-logy, 12, 83-92.

Parsons, L. M. \& Osherson, D. (2001). New evidence for distinct right and left brain systems for deductive versus probabilistic reasoning. Cerebral Cortex, 11 (10), 954-965.

Rinsiyah, I. (2016). Pengembangan modul fisika berbasis CTL untuk meningkatkan KPS dan sikap ilmiah siswa Madrasah Aliyah. Jurnal Pendidikan Matematika dan Sains, 4 (2), 152 - 162. doi:http://dx.doi.org/10.21831/jpms.v4i2 .12979

Sandoval, W. A., \& Reiser, B. J. (2003). Explanation-driven inquiry: Integrating conceptual and epistemic scaffolds for scientific inquiry. The Journal of The Learning Sciences, 12(1), 5-51.

Scheiner, W. (2008). the development of metacognitive knowledge in children and adolescents: Major trends and implica-tions for education. Journal of Mind, Brain, and Education. 2 (3), 114121.

Trianto. (2009). Mendesain model pembelajaran inovatif-progresif: Konsep, landasan, dan implementasinya pada kurikulum tingkat satuan pendidikan (KTSP). Jakarta: Kencana Prenada Media Group.

Williams, W. M., Papierno, P. B., Makel, M.C., \& Ceci, S. J. (2004). Thinking like a scientist about real-world problems: The cornell institute for research on children science education program. Applied Developmental Psychology, 25, 107126. 
Ya-Wen Liao., \& Hsiao-Ching She. (2009). Enhancing eight grade students' scientific reasoning throught a web-based learning program. Education Technology \& Society, 12 (4), 228-240.

\section{PROFIL SINGKAT}

Yulia F. Lamapaha, S. Pd. dilahirkan di Langgur - Maluku Tenggara pada tanggal 22 September 1984. Tahun 2008, menyelesaikan studi S1 Pendidikan Biologi pada FKIP Universitas Pattimura Ambon. Tahun 2009, diangkat menjadi PNS dan mengajar pada SMP Negeri Unggulan Kabupaten Maluku Tenggara. Tahun 2012, berkesempatan mengikuti Program Magister pada Progrram Studi Pendidikan Sains PPs
Universitas Negeri Yogyakarta dan Lulus Tahun 2014.

Prof. Dr. Djukri, MS. dilahirkan di Bantul DI Yogyakarta pada Tanggal 12 Juli 1948. Beliau adalah Guru Besar yang mengajar bidang biologi di Universitas Negeri Yogyakarta. Gelar sarjana biologi diraih di UGM (1977), pendidikan S2 di IPB (1984), kemudian gelar doktor diraih di IPB pada tahun 2003. Sampai saat ini beliau masih aktif mengajar di UNY. Beliau juga aktif dalam berbagai kegiatan penelitian dan pengabdian kepada masyarakat, dan pernah meraih penghar-gaan Satyalancana Karya Satya dari Presiden Republik Indonesia pada tahun 2009. 